\title{
Human T-Cell Leukemia Virus Type I Tax Associates with and Is Negatively Regulated by the NF-кB2 p100 Gene Product: Implications for Viral Latency

\author{
CHRISTOPHE BÉRAUD, ${ }^{1}$ SHAO-CONG SUN, ${ }^{1}$ PARHAM GANCHI, ${ }^{1}$ DEAN W. BALLARD, ${ }^{2}$
} AND WARNER C. GREENE ${ }^{1 *}$
}

\author{
Gladstone Institute of Virology and Immunology, University of California, San Francisco, and San Francisco \\ General Hospital, San Francisco, California 94141-9100, ${ }^{1}$ and Howard Hughes Medical Institute, \\ Vanderbilt University, Nashville, Tennessee 37232-0295
}

Received 23 July 1993/Returned for modification 2 September 1993/Accepted 4 November 1993

\begin{abstract}
Human T-cell leukemia virus type I (HTLV-I) is the etiologic agent of the adult T-cell leukemia, an aggressive and often fatal malignancy of activated human CD4 T cells. HTLV-I encodes an essential 40-kDa protein termed Tax that not only transactivates the long terminal repeat of this retrovirus but also induces an array of cellular genes. Tax-mediated transformation of $\mathbf{T}$ cells likely involves the deregulated expression of various cellular genes that normally regulate lymphocyte growth produced by altered activity of various endogenous host transcription factors. In particular, Tax is capable of modulating the expression or activity of various host transcription factors, including members of the NF-KB/Rel and CREB/ATF families, as well as the cellular factors HEB-1 and p67 ${ }^{\text {SRF }}$. An additional distinguishing characteristic of HTLV-I infection is the profound state of viral latency that is present in circulating primary leukemic $T$ cells. In this study, we demonstrate that HTLV-I Tax can physically associate with p100, the product of the Rel-related NF-kB2 gene, both in transfected cells and in HTLV-I-infected leukemic T-cell lines. Furthermore, the physical interaction of Tax with p100 leads to the inhibition of Tax-induced activation of the HTLV-I and human immunodeficiency virus type 1 long terminal repeats, reflecting p100-mediated cytoplasmic sequestration of the normally nuclearly expressed Tax protein. In contrast, a mutant of Tax that selectively fails to activate nuclear NF-kB expression does not associate with p100. Together, these results suggest that the cytoplasmic interplay of Tax and p100 may play an important role in the initiation and maintenance of HTLV-I latency observed in adult T-cell leukemia.
\end{abstract}

Human T-cell leukemia virus type I (HTLV-I) is a type C retrovirus that has been etiologically linked with adult T-cell leukemia (ATL) $(61,87)$ and more recently with a chronic demyelinating disease termed tropical spastic paraparesis $(30,60)$. ATL is geographically localized in regions of the world where HTLV-I infection is endemic, notably southern Japan, sub-Saharan Africa, the Caribbean basin, and parts of the southeastern United States $(11,12,17,23,27,32,39,48)$. This highly aggressive and often fatal neoplasm of CD4 T cells is frequently characterized by tumor cell invasion of skin and lymph nodes and may be associated with hypercalcemia and osteolysis $(11,12,17,32,44,47,83)$.

Although the precise mechanism(s) is not well understood, several independent lines of evidence suggest that the HTLV-I-encoded transactivator, Tax, plays a central role in CD4 T-cell transformation. Specifically, Tax transforms mouse or rat fibroblastoid cell lines $(73,82)$ or primary rat fibroblasts in cooperation with the ras oncogene (62). Furthermore, transgenic mice expressing Tax have been shown to develop mesenchymal tumors $(38,56)$. However, the long period of clinical latency coupled with the low incidence of ATL development in HTLV-I-infected individuals $(<1 \%)$ suggests that a multistep process of transformation is likely involved (72). In this regard, mutations in the p53 tumor

* Corresponding author. Mailing address: Gladstone Institute of Virology and Immunology, P.O. Box 419100, San Francisco, CA 94141-9100. Phone: (415) 695-3800. Fax: (415) 826-1617. Electronic mail address: Warner_Greene@quickmail.ucsf.edu. suppressor gene have recently been detected in some ATL cell lines, raising the possibility that the altered function of this particular cellular protein may contribute to the development of leukemia $(18,67)$.

Tax has been shown to activate an array of transcription units, including the HTLV-I long terminal repeat (LTR) itself $(19,75)$, the proto-oncogene c-fos $(1,25,54)$, the human immunodeficiency virus type 1 (HIV-1) LTR (13), and various cellular genes involved in T-cell growth, including the interleukin- 2 gene $(50,70)$ and the $\alpha$ subunit of its high-affinity receptor $(21,42,70)$. The ability of Tax to induce the expression of growth-related genes that normally mediate physiologic T-cell activation and cell cycle progression provides one attractive explanation for the polyclonal proliferation of T cells observed early after HTLV-I infection (35). This initial proliferative response presumably serves to facilitate the occurrence of subsequent undefined genetic events that complete the transformation process.

In light of the inability of Tax to directly engage DNA, the unusually large number of cellular genes activated by this retroviral protein is likely explained by its capacity to modulate various host transcription factor pathways. These pathways include the CREB/ATF family of proteins and the HEB-1 cellular factor responsible for activation of the HTLV-I LTR $(9,81,89,90)$, the p67 $7^{\mathrm{SRF}}$ factor which mediates induction of c-fos (26), and the NF- $\mathrm{kB} / \mathrm{Rel}$ family which mediate activation of the interleukin-2 receptor $\alpha$-subunit gene and the HIV-1 LTR $(7,13,20,64)$. Indeed, Tax has been shown to physically interact with some of these factors $(9,26,40,81,89,90)$. 
Members of the NF- $\mathrm{B} / \mathrm{Rel}$ family of transcription factors are each characterized by an $\mathrm{N}$-terminal $\approx 300$-amino-acid segment termed the Rel homology domain. This domain is responsible for DNA binding, dimerization, and nuclear localization of these factors $(33,34)$. Members of the Rel family include the oncoprotein $\mathrm{v}$-Rel $(77,85)$, its cellular homolog c-Rel $(16)$, p50 $(31,46,53)$, p52 $(15,57,68)$, p65 $(58$, 65), RelB (66), and the Drosophila morphogen Dorsal (78). Heterodimeric combinations of p50 and p65 constitute the prototypical NF- $\mathrm{kB}$ complex (6), which stimulates transcription by a mechanism involving a potent transactivation domain located within the C-terminal half of p65 $(8,65,69)$. Both $\mathrm{p} 50$ and $\mathrm{p} 52$ are proteolytic cleavage products of larger precursor proteins, termed p105 (NF-kB1 gene product) (14, $22,31,46,53)$ and p100 (NF-kB2 gene product) $(15,51,57$, $68)$, respectively.

One unique feature of the NF- $\mathrm{kB} / \mathrm{Rel}$ transcription factor system is that the involved factors are regulated posttranscriptionally through interactions with a set of cytoplasmic inhibitory proteins termed IאB $(3-5,84)$. Each of these inhibitors contains a domain remarkable for the presence of multiple arkyrin motifs which appear to be essential for their biological functions. The IkB proteins identified so far include I $\mathbf{k} \boldsymbol{\alpha}$ (formerly called I $\mathbf{B} / \mathrm{MAD} 3)(36,88)$, I $\mathbf{B} \beta(88)$, IкB $\gamma$, which corresponds to the C-terminal half of p105 (37, $43,49), \mathrm{Bcl}-3(24,37,59,86)$, and the Drosophila maternal protein Cactus $(29,45)$. Remarkably, the p105 $(55,63)$ and p100 $(52,80)$ precursors of p50 and p52 also contain C-terminal ankyrin repeats and have been shown to possess IкB-like biological activities.

In this report, we demonstrate that HTLV-I Tax specifically interacts with the p100 protein product of the NF-кB2 gene. Surprisingly, only a weak interaction was detected between Tax and the p105 protein product of the NF-kB1 gene. Functionally, the interaction of p100 and Tax results in the marked down-regulation of Tax-mediated activation of the HTLV-I LTR. These inhibitory effects of p100 are correlated with the redistribution of Tax from the nuclear to the cytoplasmic compartment. These findings suggest that the formation of Tax-p100 complexes in virally infected cells may play an important role in the establishment and maintenance of viral latency observed in HTLV-I-induced ATL.

\section{MATERIALS AND METHODS}

Plasmids. Tax, TaxM22, TaxM47 (71), p100, p52 (68), IkB $\alpha$ (36), p105 (46), and p65 (65) cDNAs were subcloned within the polylinker of the pCMV4 expression vector positioned downstream of the cytomegalovirus immediate-early promoter (2). Reporter plasmids contained either the fulllength HTLV-I LTR (75) or the HIV-1 kB enhancer cassette linked to a heterologous TATA box (76), cloned immediately upstream of the gene encoding chloramphenicol acetyltransferase (CAT).

Immunoprecipitation analysis. Subconfluent monkey kidney COS-7 cells were transfected by using DEAE-dextran (41). Approximately $40 \mathrm{~h}$ after transfection, cells were starved for $1 \mathrm{~h}$ in Dulbecco modified Eagle medium lacking methionine and cysteine and then metabolically radiolabeled for $3 \mathrm{~h}$ with $\left[{ }^{35} \mathrm{~S}\right]$ methionine and $\left[{ }^{35} \mathrm{~S}\right]$ cysteine $(300 \mu \mathrm{Ci} / \mathrm{ml})$. Whole-cell extracts were prepared by resuspending these cells in $500 \mu$ l of a low-stringency lysis buffer $(20 \mathrm{mM} \mathrm{N}-2$ hydroxyethylpiperazine- $N^{\prime}$-2-ethanesulfonic acid [HEPES; pH 7.9], $1 \mathrm{mM} \mathrm{MgCl}_{2}, 0.2 \mathrm{mM}$ EDTA, $10 \mu \mathrm{M} \mathrm{ZnCl}, 10 \%$ glycerol, $200 \mathrm{mM} \mathrm{KCl}, 0.2 \%$ Nonidet P-40, $0.5 \mathrm{mM}$ dithiothreitol, $1 \mathrm{mM}$ phenylmethylsulfonyl fluoride); $200 \mu \mathrm{l}$ of each extract was diluted to $500 \mu$ lin the same buffer and precleared for $1 \mathrm{~h}$ at $4^{\circ} \mathrm{C}$ with $1 \mu \mathrm{l}$ of normal rabbit serum (NRS) and $20 \mu$ l of protein A-agarose beads (Boehringer, Mannheim, Germany). The precleared extract was then incubated at $4^{\circ} \mathrm{C}$ with $1 \mu \mathrm{l}$ of the specific antibodies and $10 \mu \mathrm{l}$ of protein A-agarose beads for $2 \mathrm{~h}$. The agarose beads were then washed twice in the low-stringency buffer and resuspended in $30 \mu \mathrm{l}$ of $2 \times$ loading buffer $(0.125 \mathrm{M}$ Tris [pH 6.8$], 4 \%$ sodium dodecyl sulfate [SDS], $10 \% \beta$-mercaptoethanol, $30 \%$ glycerol, $0.01 \%$ bromophenol blue). After heat denaturation, $15 \mu$ l of the sample was loaded on an SDS-9\% polyacrylamide gel.

Jurkat cell transfection and CAT assay. Human Jurkat T cells were cultured in RPMI 1640 medium supplemented with $10 \%$ fetal calf serum, $2 \mathrm{mM}$ glutamine, and antibiotics. Cells were transfected with 0.5 or $2 \mu \mathrm{g}$ of CAT reporter plasmid and various amounts of expression plasmids, using DEAE-dextran (41). DNA concentration was held constant in all transfections, using the parental pCMV4 vector. Approximately $40 \mathrm{~h}$ after transfection, relative CAT activities were determined as previously described (28).

Indirect immunofluorescence. COS-7 cells were cultured in four-well chamber slides (Nunc, Naperville, Ill.) and transfected with various expression plasmids, using DEAE-dextran. Approximately $48 \mathrm{~h}$ after transfection, cells were fixed, permeabilized, and stained for indirect immunofluorescence as previously described (28). Cells were observed with a UV light microscope (Leitz, Heerbrug, Switzerland).

Immunoblot analysis of ATL cell lines. The HTLV-Iinfected cell lines HUT102 and C8166 were cultured in RPMI 1640 medium supplemented with $10 \%$ fetal calf serum, $2 \mathrm{mM}$ glutamine, and antibiotics. Subcellular protein extracts from these cells were prepared and immunoprecipitated with NRS or anti-Rex, anti-p100, and anti-Tax antibodies.

Immunoprecipitates were fractionated on SDS-polyacrylamide gels, transferred to nitrocellulose, and immunoblotted with anti-p100 or anti-Tax, using an enhanced chemiluminescence system as specified by the manufacturer (Amersham International, Amersham, England).

\section{RESULTS}

Tax physically interacts with the NF-kB2 gene product p100 through its $\mathbf{N}$-terminal domain. To investigate the potential interaction of Tax with p100 or its proteolytically processed form, p52, coimmunoprecipitation experiments were performed with whole-cell extracts from COS cells cotransfected with combinations of expression vectors encoding p100, p52, and Tax (Fig. 1A). After transfection, the cells were metabolically radiolabeled with $\left[{ }^{35} S\right]$ methionine and $\left[{ }^{35} \mathrm{~S}\right]$ cysteine, and the cell lysates were immunoprecipitated with an antiserum directed against either the $\mathrm{C}$ terminus of Tax or the $\mathrm{N}$ terminus of $\mathrm{p} 100$. In cells transfected with Tax alone, a specific band of $40 \mathrm{kDa}$ corresponding to the Tax protein was specifically immunoprecipitated with an antiTax antiserum (lane 2); however, this antibody failed to cross-react with either p100 or p52 (lanes 3 and 4). In contrast, in extracts from cells cotransfected with Tax and p100 or p52, both p100 and p52 were coimmunoprecipitated with Tax (lanes 5 and 6 ) by the anti-Tax antibody. Of note, p52 was also detected in the extracts from p100-transfected cells, apparently reflecting physiological processing of p100 to p52 (lane 5). Under these coimmunoprecipitation conditions, Tax consistently bound p100 more avidly than p52 for reasons that remain unclear (compare lanes 5 and 6 ). Complementary coimmunoprecipitation experiments were per- 
A

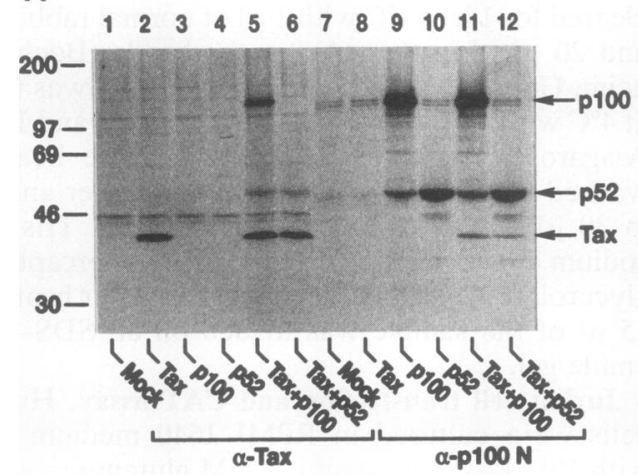

C

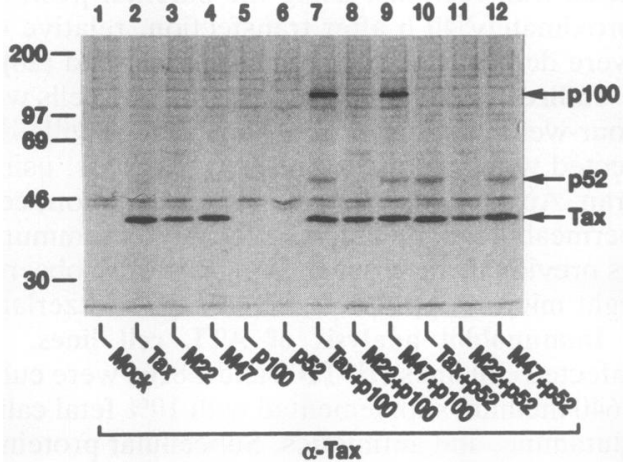

B

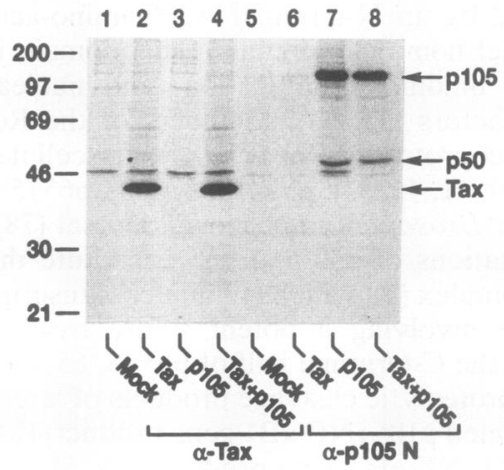

$1314151617 \quad 18192021 \quad 22 \quad 2324$

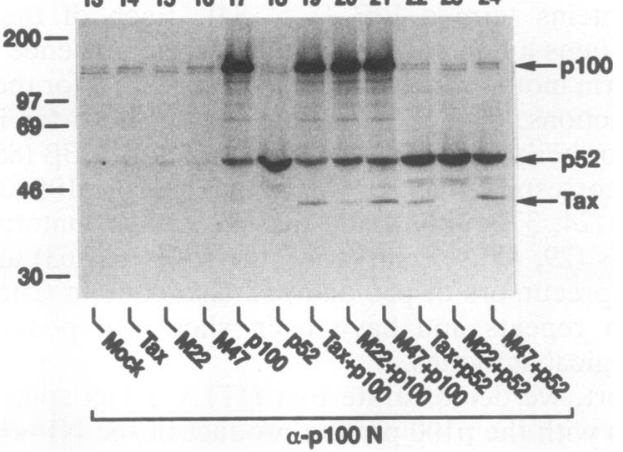

FIG. 1. Physical interaction of HTLV-I Tax with the NF-kB2 gene product p100 and its processed product p52. (A) Coimmunoprecipitation of Tax and p100 or p52. Subconfluent COS-7 cells were transfected with the parental control expression vector pCMV4 (lanes 1 and 7), Tax (lanes 2 and 8), p100 (lanes 3 and 9), p52 (lanes 4 and 10), or combinations of Tax and p100 (lanes 5 and 11) or Tax and p52 (lanes 6 and 12). Approximately $40 \mathrm{~h}$ after transfection, cells were metabolically radiolabeled and whole-cell extracts were prepared. These extracts were then subjected to immunoprecipitation with antiserum specific for the $C$ terminus of Tax (amino acids 321 to 353; lanes 1 to 6) or the $\mathrm{N}$ terminus of p100 (amino acids 1 to 21 ; lanes 7 to 12). Immunoprecipitates were analyzed by electrophoresis on an SDS-9\% polyacrylamide gel. The p100, p52, and Tax proteins are identified by labeled arrows on the right; the migration of known molecular weight markers is identified in kilodaltons on the left. (B) Coimmunoprecipitation studies of Tax and the NF-kB1 gene product p105. Subconfluent COS-7 cells were transfected with the parental control expression vector pCMV4 (lanes 1 and 5), Tax (lanes 2 and 6), p105 (lanes 3 and 7), or a combination of Tax and p105 (lanes 4 and 8). Cells were identically radiolabeled, and extracts were immunoprecipitated with anti-Tax (lanes 1 to 4) or antibody specific for the $\mathrm{N}$ terminus of p105 (amino acids 1 to 21; lanes 5 to 8). The p105, p50, and Tax proteins are identified. (C) Mutant TaxM22 fails to interact with p100 or p52, while mutant TaxM47 still binds to p100 and p52. Subconfluent COS-7 cells were transfected with the parental expression vector pCMV4 (lanes 1 and 13), Tax (lanes 2 and 14), TaxM22 (lanes 3 and 15), TaxM47 (lanes 4 and 16), p100 (lanes 5 and 17), p52 (lanes 6 and 18), Tax and p100 (lanes 7 and 19), TaxM22 and p100 (lanes 8 and 20), TaxM47 and p100 (lanes 9 and 21), Tax and p52 (lanes 10 and 22), TaxM22 and p52 (lanes 11 and 23), or TaxM47 and p52 (lanes 12 and 24). The corresponding radiolabeled extracts were subjected to immunoprecipitation with the anti-Tax antiserum (lanes 1 to 12) or the anti-p100 antiserum (lanes 13 to 24). p100, p52, and Tax proteins are identified.

formed with an antiserum specific for the $\mathrm{N}$-terminal region of p100. Consistent with results obtained with use of antiTax, Tax was coimmunoprecipitated with both p100 (lane 11) and p52 (lane 12), although the overall level of Tax recovery was less than the amounts of p100 and p52 recovered in the anti-Tax immunoprecipitation experiment. Together, these findings demonstrate that Tax physically interacts with the NF-kB2 precursor gene product $\mathrm{p} 100$ and its processed $\mathrm{p} 52$ counterpart.

Tax interacts very weakly with p105 compared with p100. Hirai et al. (40) have recently reported that Tax physically interacts with p105, the product of the NF-kB1 gene and precursor of the p50 subunit of NF-kB. Coimmunoprecipitation studies were next performed to compare the p105-Tax interaction with the p100-Tax interaction (Fig. 1B). Anti-Tax immunoprecipitation of extracts from cells cotransfected with both Tax and p105 expression vectors revealed the presence of Tax but only trace amounts of p105 (lane 4). Similarly, using a p105-specific antiserum, only a very faint band corresponding to coimmunoprecipitated Tax was detected (lane 8). These results suggest that the interaction of Tax with p105 is quite weak compared with the interaction observed between Tax and p100.

Mutant TaxM22, which is unable to activate NF-eB, interacts poorly with p100. Previous studies have resulted in the identification of $\operatorname{Tax}$ mutants that functionally segregate NF- $\kappa$ B/Rel-mediated transactivation of the HIV-1 LTR (NF$\kappa B)$ from CREB/ATF/HEB-1-mediated activation of the HTLV-I LTR (71). Specifically, mutant TaxM22 (Gly Leu $\rightarrow$ Ala Ser at residues 137 and 138) lacks the ability to activate the HIV-1 LTR yet is fully functional with respect to activation of the HTLV-I promoter. In contrast, mutant 


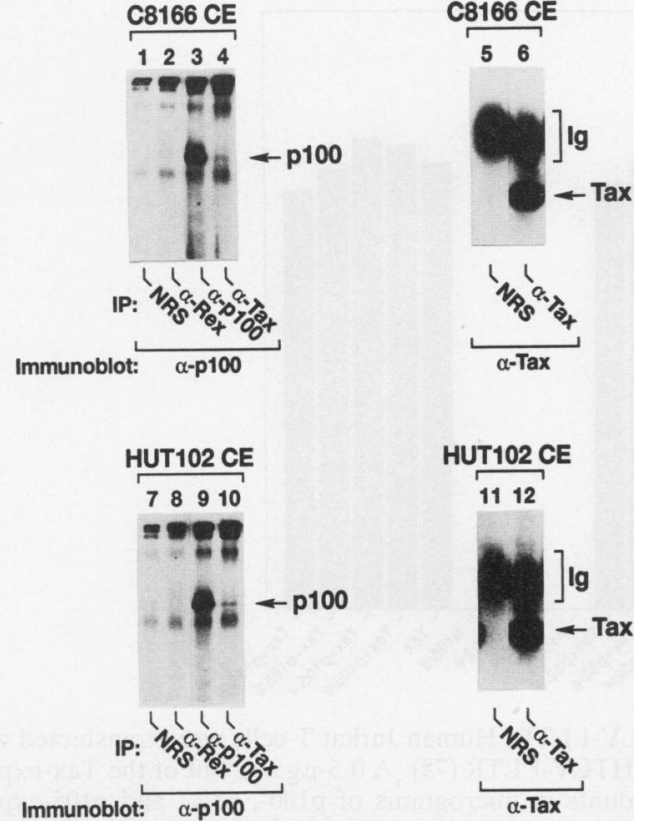

FIG. 2. Tax associates with p100 in HTLV-I-infected T-cell lines. Cytoplasmic extracts (CE; $400 \mu \mathrm{g}$ ) from the Tax-expressing HTLV-I-infected C8166 (lanes 1 to 6) and HUT102 (lanes 7 to 12) cell lines were prepared and subjected to immunoprecipitation (IP) with either preimmune NRS (lanes 1, 5, 7, and 11), anti-Rex-specific peptide antibodies specific for amino acids 173 to 186 (lanes 2 and 8), anti-p100 antiserum (lanes 3 and 9), or anti-Tax antibodies (lanes 4, 6,10 , and 12). The immunoprecipitates were then electrophoresed on SDS-9\% polyacrylamide gels and subjected to immunoblotting with the anti-p100 antibodies (lanes 1 to 4 and 7 to 10) or the anti-Tax antibodies (lanes 5, 6, 11, and 12), using the enhanced chemiluminescence system. Migration of the p100 and Tax proteins is indicated. Ig, immunoglobulin.

TaxM47 (Leu Leu $\rightarrow$ Arg Ser at residues 319 and 320) fails to activate the HTLV-I promoter but retains the capacity to stimulate the HIV-1 LTR. In light of these distinct phenotypic properties, we next tested each Tax mutant for its ability to interact with p100 (Fig. 1C). As shown in lanes 8 and 11 , TaxM22 only weakly associated with p100 or p52, respectively. In contrast, as shown in lanes 9 and 12, TaxM47 interacted strongly with p100 and p52 in a manner similar to that found for the wild-type Tax protein (lanes 7 and 10). TaxM22 was only weakly coimmunoprecipitated with p100 (lane 20) or p52 (lane 23) when anti-p100 antiserum was used. In contrast, TaxM47 was readily coimmunoprecipitated by the anti-p100 antibody (compare lanes 21 and 24 with lanes 19 and 22). These coimmunoprecipitation studies thus indicate that the Tax-p100 interaction is quite specific, since a missense mutation affecting only two residues in the primary sequence of Tax appears to markedly impair this interaction. In addition, the finding that TaxM 22 both fails to activate NF-kB and only weakly interacts with p100 suggests that this interaction may be functionally important in the mechanism by which Tax deregulates the normally inducible pattern of NF- $\mathrm{kB}$ expression in CD4 T cells.

Tax is physically associated with p100 in HTLV-I-infected T-cell lines. To ensure that the Tax-p100 interaction detected in transfected COS cells was not an artifact of the overexpression conditions, two Tax-expressing HTLV-I-infected T-cell lines were used for coimmunoprecipitation studies (Fig. 2). Cytoplasmic extracts prepared from C8166 or
HUT102 cell lines were immunoprecipitated with NRS or with anti-Rex, anti-p100, or anti-Tax serum and then immunoblotted with p100-specific antiserum. As shown in lanes 4 and 10 , a band comigrating with p100 was coprecipitated with anti-Tax from both the C8166 and the HUT102 extracts but not with either NRS (lanes 1 and 7) or anti-Rex (lanes 2 and 8). Of note, the amount of p100 coprecipitated with Tax in HTLV-I-infected cells appeared significantly less than that observed in extracts from transfected COS cells. This finding could suggest that the interaction between Tax and p100 in these cell lines is comparably weaker; however, this difference likely reflects higher steady-state levels of the p100 protein in transfected COS cells compared with the levels of endogenous p100 protein in the HTLV-I-infected cell lines. The expression of Tax in the C8166 and HUT102 cytoplasmic extracts was confirmed by submitting the immunoprecipitates to immunoblotting with anti-Tax antiserum. As shown in lanes 6 and 12, a band corresponding to Tax was precipitated with anti-Tax from both the C8166 and HUT102 cytoplasmic extracts.

p100 inhibits Tax-induced activation of the HTLV-I LTR. To assess the functional consequences of the interaction of p100 and Tax, the effect of coexpression of p100 on Taxmediated activation of the HTLV-I LTR was studied in Jurkat $T$ cells. As shown in Fig. 3, p100 produced dosedependent inhibition of Tax-induced stimulation of the HTLV-I LTR-CAT reporter plasmid. In contrast, coexpression of Tax and p52 did not lead to inhibition of Tax activation of the HTLV-I LTR even though p52 and Tax readily interact with each other. Consistent with the weak association observed between p105 and Tax, p105 failed to alter Tax activation of the HTLV-I LTR.

The effects of p100 on Tax-induced activation of the HIV-1 kB enhancer were similarly studied. As shown in Fig. 4 , Tax alone produced $>350$-fold activation of the $\mathrm{kB}$ enhancer element, while p100, p105, and IKB alone were without effect. Cotransfection of Jurkat $T$ cells with combinations of Tax and p100 inhibited Tax-induced activation, as did cotransfection of IKB $\alpha$. Of note, p100 was consistently more effective in inhibiting Tax-mediated activation of the HIV-1 LTR $(80 \%$ inhibition at a ratio of $1: 1)$ than the HTLV-I LTR (25\% at a ratio of $1: 4)$. In contrast, p105 exerted only weak inhibitory effects on Tax. Similarly, the same inhibitory effects of p100 were observed for p65mediated induction of the HIV-1 $\mathrm{kB}$ enhancer $(52,80)$. These data raise the possibility that this inhibition of p65 function could contribute to the p100 inhibitory effect on Tax-mediated activation of the HIV-1 $\mathbf{k B}$ enhancer element.

p100 alters the subcellular pattern of Tax expression. HTLV-I Tax has been described as principally a nuclear protein that contains a unique nuclear localization signal (74). In contrast, the expression of p100 is restricted to the cytoplasmic compartment (52). Indirect immunofluorescence studies were next performed to assess the effects of coexpression of p100 on the subcellular distribution of Tax. As shown in Fig. 5, expression of Tax alone revealed a predominantly nuclear pattern of anti-Tax staining, whereas coexpression of $\mathrm{p} 100$ and Tax led to a cytoplasmic pattern of expression (compare Fig. 5A and F). This redistributed pattern of expression was not due to an immunological cross-reaction of the anti-Tax antibody with p100, since cells transfected with p100 alone failed to show any fluorescence (Fig. 5B). In contrast to the marked subcellular retargeting effects of p100, neither p52 nor p105 altered the nuclear pattern of Tax expression (compare Fig. 5A, G, and H). Localization of mutants TaxM22 and TaxM47 was also 


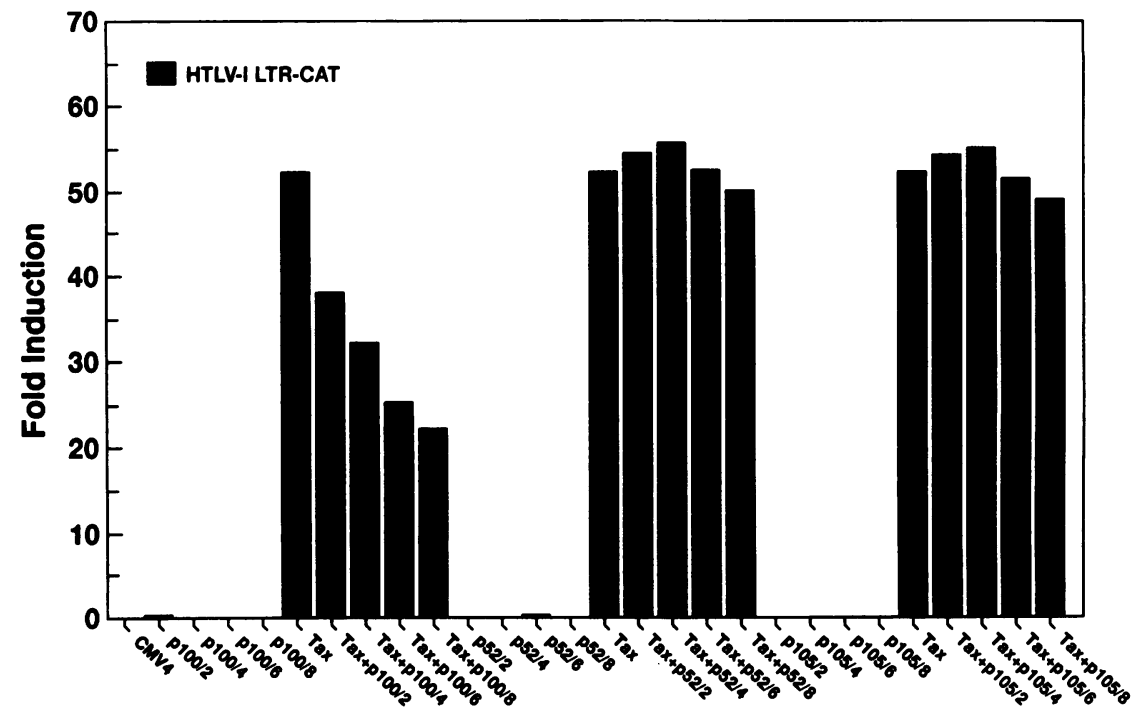

FIG. 3. p100 inhibition of the Tax-mediated transcription activation of the HTLV-I LTR. Human Jurkat T cells were transfected with the indicated plasmids together with $0.5 \mu \mathrm{g}$ of a CAT reporter plasmid containing the HTLV-I LTR (75). A 0.5- $\mu \mathrm{g}$ amount of the Tax-expressing plasmid was used, and the numbers following the slash signs represent the amounts in micrograms of p100-, p52-, and p105-expressing plasmids used. CAT activities, measured approximately $40 \mathrm{~h}$ after transfection, are presented as the relative fold induction over the basal level obtained with the parental pCMV4 expression vector. The data shown are representative of a single experiment; however, four independent CAT assays were performed and showed the same inhibition of Tax responsiveness by p100.

studied in the presence of p100. Consistent with the weak association of TaxM22 and p100 (Fig. 1C), TaxM22 remained nuclear (compare Fig. 5D and I), while TaxM47, which effectively binds to p100, was retargeted to the cytoplasm (compare Fig. 5E and J). Using antisera directed against p100 and p105, we controlled that p100 (Fig. 5K, N, and 0 ), p52 (Fig. 5L), and p105 (Fig. 5M) were readily expressed in the coexpression experiments.

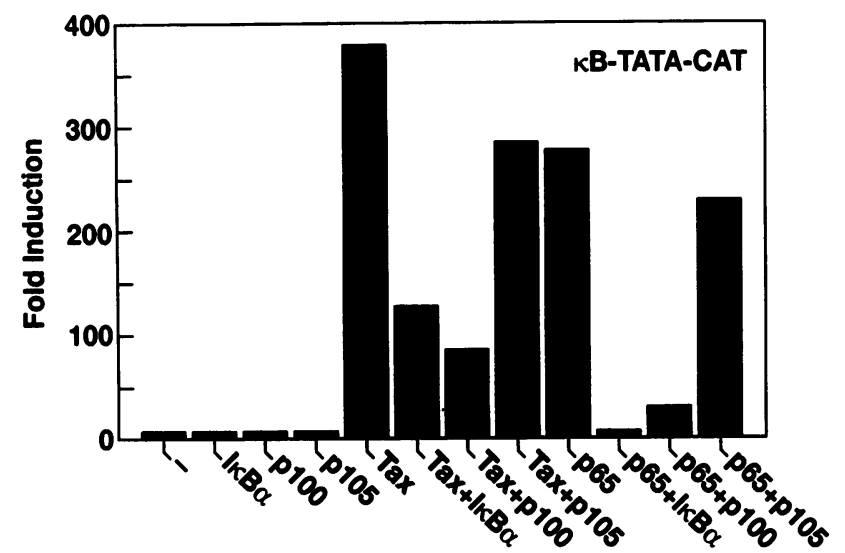

FIG. 4. p100 inhibition of the Tax-mediated transcriptional activation of the HIV-1 $\mathrm{kB}$ enhancer. Human Jurkat $\mathrm{T}$ cells were transfected with $2 \mu \mathrm{g}$ of the indicated plasmids together with $2 \mu \mathrm{g}$ of a CAT reporter plasmid containing the HIV-1 $\mathrm{kB}$ enhancer $(\mathrm{kB}$ TATA-CAT) (76). CAT activities, measured approximately $40 \mathrm{~h}$ after transfection, are presented as the relative fold induction over the basal level obtained with the parental pCMV4 expression vector. The data shown are representative of a single experiment; however, three independent experiments were performed and showed the same results.

\section{DISCUSSION}

In this report, we provide evidence for a physical and functional interaction between the HTLV-I Tax transactivator and p100, the Rel-related product of the NF-kB2 gene. This interaction is mediated through sequences located in the N-terminal half of $\mathrm{p} 100$ since $\mathrm{p} 52$, a processed form of p100 that lacks the C-terminal ankyrin repeat domain, retains the capacity to associate with Tax. This interaction of Tax and p100 is not restricted to cells transfected with Tax and p100 expression vectors but has also been detected in the more physiological cellular context of HTLV-I-infected human T-cell lines. In sharp contrast to the strong p100-Tax interaction detected in these coimmunoprecipitation assays, only a very weak association of Tax and p105, the product of the NF-кB1 gene, was demonstrated. This result contrasts with the prior report of Hirai and colleagues (40), who have described both in vitro and in vivo evidence for the association of Tax and p105; p100 was, however, not similarly studied. The bases for these disparate results remain unexplained but may simply reflect differences in the sensitivity of the various detection assays. In addition, the p105 expression vector used in our studies contains wild-type sequences at the extreme $\mathrm{N}$ terminus, while the p105 vector used by Hirai and coworkers is remarkable for a deletion within this region. Whether this difference contributes to the efficacy of p105 binding to Tax remains to be determined. Notwithstanding, it is clear that the association of p100 with Tax is far stronger than that observed with p105. More importantly, no functional consequences have yet been attributed to the p105-Tax interaction, while as noted below, the formation of p100-Tax complexes leads to inhibition of Tax function.

These findings regarding the physical interaction of Tax with the Rel-related p100 protein extend earlier reports regarding the physical association of Tax with transcription factors such as members of the CREB/ATF family and HEB-1 $(9,81,89,90)$. These cellular proteins directly engage 


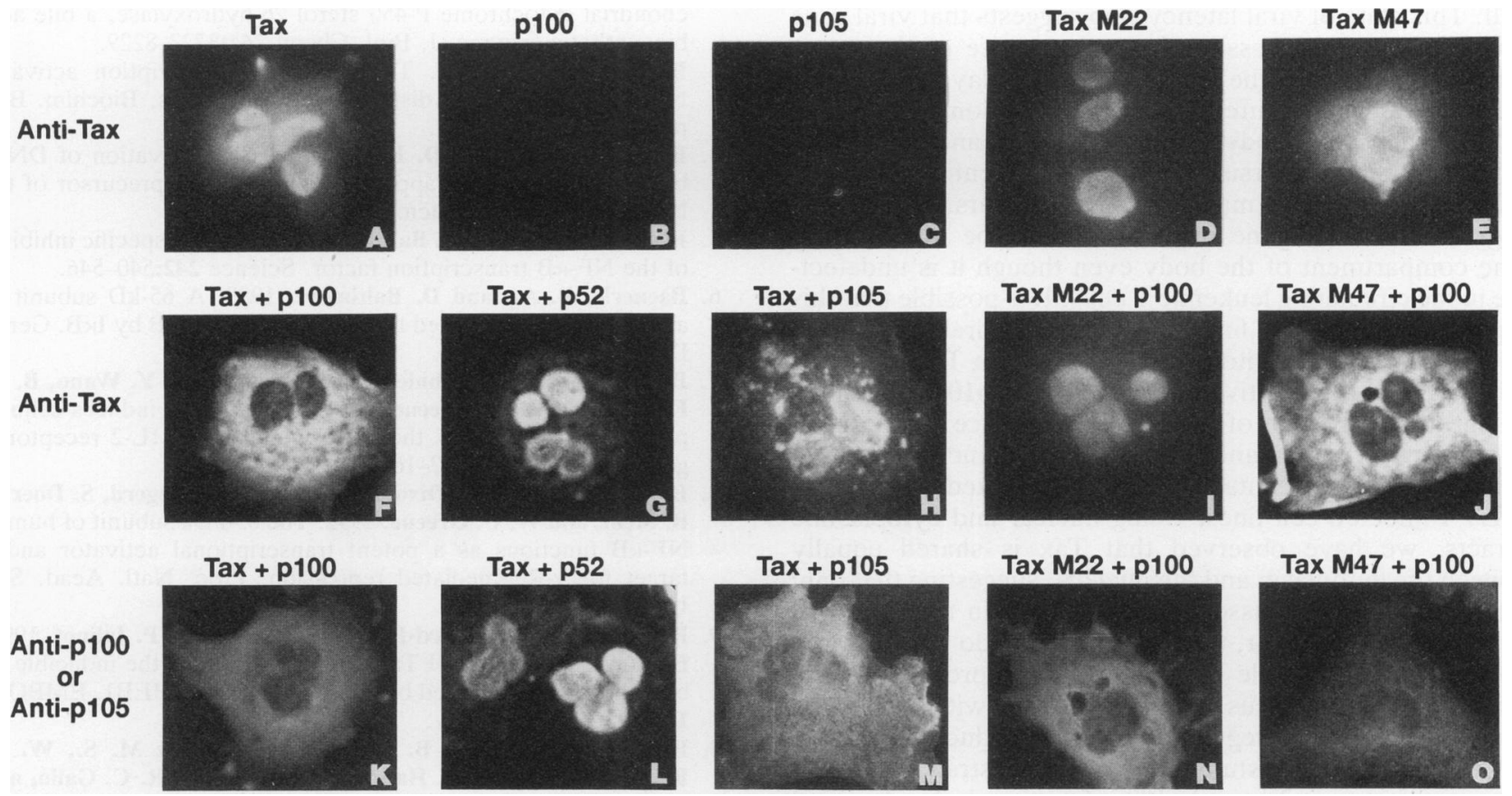

FIG. 5. Subcellular localization of Tax in the presence and absence of p100. COS-7 cells were transfected with Tax (A), p100 (B), p105 (C), TaxM22 (D), TaxM47 (E), Tax plus p100 (F and K), Tax plus p52 (G and L), Tax plus p105 (H and M), TaxM22 plus p100 (I and N), or TaxM47 plus p100 (J and O). After $48 \mathrm{~h}$, the cells were fixed, incubated with the antiserum specific for the $\mathrm{C}$ terminus of Tax (A to J), the $\mathrm{N}$ terminus of p100 $(\mathrm{K}, \mathrm{L}, \mathrm{N}$, and $\mathrm{O})$, or the $\mathrm{N}$ terminus of p105 $(\mathrm{M})$ and then subjected to indirect immunofluorescence staining using Texas red-conjugated anti-rabbit immunoglobulins.

the three 21-bp repeats present in the HTLV-I LTR. Presumably, the indirect tethering of Tax to these factors endows this complex with unique functional properties that underly Tax-mediated transactivation of the HTLV-I LTR.

In contrast to Tax-CREB/HEB-1, studies of the p100-Tax interaction have revealed a very different functional consequence. Indeed, the association of Tax with p100 leads to the marked inhibition of Tax-induced activation of both the HTLV-I LTR and the HIV-1 $\mathrm{kB}$ enhancer. The doseresponse difference observed for p100 inhibition of Taxmediated activation of the HTLV-I LTR versus the HIV-1 LTR may stem from differences in the sensitivity of these two promoters to the HTLV-I Tax protein. Specifically, the HTLV-I LTR may respond well at lower concentrations of Tax. As judged from results from indirect immunofluorescence studies, this inhibition by p100 is correlated with retargeting of Tax expression from the nuclear to the cytoplasmic compartment. In this regard, these inhibitory effects of the cytoplasmic p100 protein are not recapitulated by $\mathrm{p} 52$, which when expressed alone accumulates in the nucleus. These findings suggest that the C-terminal sequences removed in the processing of p100 to p52 are critical for functional inhibition of $\operatorname{Tax}$ and retargeting of this viral transactivator to the cytoplasm. These deleted sequences are notable for the presence of the multiple ankyrin repeats known to be required for the retention of p100 in the cytoplasm (52). These ankyrin repeats also play a critical role in p100-mediated inhibition of NF-kB p65 function, a response that similarly involves cytoplasmic sequestration of the p65 subunit $(52,80)$. Recent studies have demonstrated that both p100 and p105 can function as IKB-like molecules for various Rel family members, including p65 and c-Rel $(52,55,63,80)$. Thus, p100 not only sequesters Tax in the cytoplasm but also sequesters p65 and c-Rel, leading to the inhibited function of these Rel-related transcription factors.

NF-kB p65, Tax, and p100 are also functionally linked in another potentially related regulatory pathway. Among its many effects, Tax expression leads to the activation of nuclear NF- $\mathrm{KB}$ expression. Our recent studies demonstrate that the p65 subunit of NF-kB in turn stimulates not only IKB- $\alpha$ expression (79) but also NF- $\mathrm{KB} 2$ gene expression, leading to increased p100 protein levels $(80)$. Similarly, twoto threefold-higher levels of p100 protein and NF-kB2 mRNA are detectable in Tax-expressing ATL cells compared with ATL cells that lack this retroviral function (data not shown). The ensuing binding of p100 to both Tax and p65 serves to down-regulate the functional activity of each, thus highlighting a negative feedback loop involving a single cytoplasmic inhibitor that affects both Tax and p65 action.

One potential implication from these studies is that the observed inhibitory effects of p100 on Tax-mediated function may play a role in the profound state of viral latency characteristic of HTLV-I-infected cells in vivo. Even by using sensitive approaches involving reverse transcription coupled with PCR amplification, it has been difficult to demonstrate viral RNA expression in circulating leukemic T cells (10). However, given that a severalfold excess of p100 appears necessary to inhibit Tax-mediated activation of the HTLV-I LTR, this effect may play only a marginal role in the latency associated with HTLV-I infection. These inhibitory effects of p100 are probably only one of the mechanisms responsible for the viral latency; however, we believe that they are highly significant. Indeed, transfected cells only partially reflect what occurs in the infected cells and particularly the very tight regulation of p100 expression by Tax 
itself. This state of viral latency also suggests that viral gene expression is not necessary for maintenance of the transformed state. Rather, the virus might have played its pivotal role at an earlier juncture in the transformation process. On the other hand, antibody responses to Tax and other viral proteins appear to persist throughout the entire period of clinical latency, which may span 20 to 30 years. This finding suggests that viral gene expression must be occurring in some compartment of the body even though it is undetectable in the circulating leukemic T cells. It is possible that this response reflects the fine regulation of viral expression controlled by the inhibitory effect of p100 on Tax-mediated activation and the positive effect of Tax on p100 expression through the activation of $\mathrm{p} 65$. The importance of the interaction between p100 and Tax in viral latency raises the question of what percentage of Tax is associated with p100 in HTLV-I-infected cell lines. Using nuclear and cytoplasmic extracts, we have observed that Tax is shared equally between the cytoplasm and the nucleus, suggesting that only half of the protein is associated with p100 in the HTLV-Iinfected cells. However, these experiments do not take into account the remarkable dynamics of Tax production and transport into the nucleus versus association with p100 in the cytoplasm and the up-regulation of $\mathrm{p} 100$ production by Tax.

While this present study clearly demonstrates that the interaction between Tax and p100 is functional, the observed inhibitory effects of p100 on Tax fail to provide definitive insights into the mechanism by which Tax activates nuclear expression of members of the NF-kB/Rel family. Specifically, our finding that mutant TaxM22, which cannot induce NF-KB expression, binds only weakly to p100 or p52 strongly suggested that the interaction of Tax and p100 or p52 might be critically involved in the induction of NF-kB. In this context, we considered several mechanistic explanations including, that (i) Tax binding to p100 might accelerate its posttranslational cleavage to $\mathrm{p} 52$, which in turn facilitates the nuclear expression of this Rel family member, and (ii) Tax binding to p100 inhibits its IKB-like function, perhaps by releasing p100 from known transactivating subunits such as p65 or c-Rel, thereby allowing their nuclear import. Thus far, however, we have been unable to show that Tax accelerates p100 posttranscriptional cleavage to $\mathrm{p} 52$. Furthermore, recent in vitro studies suggest that Tax does not displace p65 bound to p100 (data not shown). As such, the mechanism by which Tax induces the constitutive nuclear expression of NF-kB/Rel in virally infected cells remains enigmatic. Notwithstanding, it has become increasingly clear that HTLV-I Tax participates in a diverse array of protein-protein interactions within host CD4 T cells, some of which potentiate its transcriptional activating properties, while others, notably its binding to p100, appear to antagonize its biological actions.

\section{ACKNOWLEDGMENTS}

We thank A. Israel for providing the p105 cDNA, G. Nabel for the p100 and p52 cDNAs, A. Baldwin for the human IkB $\alpha / M A D-3$ cDNA, C. Rosen for the human p65 cDNA, and Kathleen Rañeses for preparation of the manuscript.

D.W.B. was supported by the Howard Hughes Medical Institute.

\section{REFERENCES}

1. Alexandre, C., and B. Verrier. 1991. Four regulatory elements in the human c-fos promoter mediate transactivation by HTLV-I Tax protein. Oncogene 6:543-551.

2. Andersson, S., D. Davis, H. Dahlback, H. Jornvall, and K. W. Russell. 1989. Cloning, structure, and expression of the mito- chondrial cytochrome P-450 sterol 26-hydroxylase, a bile acid biosynthetic enzyme. J. Biol. Chem. 264:8222-8229.

3. Baeuerle, P. A. 1991. The inducible transcription activator NF- $\mathrm{kB}$ : regulation by distinct protein subunits. Biochim. Biophys. Acta 1072:63-80.

4. Baeuerle, P. A., and D. Baltimore. 1988. Activation of DNAbinding activity in an apparently cytoplasmic precursor of the NF- $\mathrm{kB}$ transcription factor. Cell 53:211-217.

5. Baeuerle, P. A., and D. Baltimore. 1988. IKB: a specific inhibitor of the NF-kB transcription factor. Science 242:540-546.

6. Baeuerle, P. A., and D. Baltimore. 1989. A $65-\mathrm{kD}$ subunit of

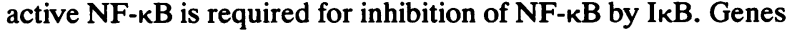
Dev. 3:1689-1698.

7. Ballard, D. W., E. Böhnlein, J. W. Lowenthal, Y. Wano, B. R. Franza, and W. C. Greene. 1988. HTLV-I Tax induces cellular proteins that activates the $\mathrm{\kappa B}$ element in the IL-2 receptor $\alpha$ gene. Science 241:1652-1654.

8. Ballard, D. W., E. P. Dixon, N. J. Peffer, H. Bogerd, S. Doerre, B. Stein, and W. C. Greene. 1992. The 65-kDa subunit of human $\mathrm{NF}-\mathrm{\kappa B}$ functions as a potent transcriptional activator and a target for v-Rel-mediated repression. Proc. Natl. Acad. Sci. USA 89:1875-1879.

9. Béraud, C., G. Lombard-Platet, Y. Michal, and P. Jalinot. 1991. Binding of the HTLV-I Tax1 transactivator to the inducible 21 bp enhancer is mediated by the cellular factor HEB1. EMBO J. 10:3795-3803.

10. Berneman, Z. N., R. B. Gartenhaus, J. Reitz M. S., W. A. Blattner, A. Manns, B. Hanchard, O. Ikehara, R. C. Gallo, and M. E. Klotman. 1992. Expression of alternatively spliced human T-lymphotropic virus type I pX mRNA in infected cell lines and in primary uncultured cells from patients with adult T-cell leukemia/lymphoma and healthy carrier. Proc. Natl. Acad. Sci. USA 89:3005-3009.

11. Blattner, W. A., D. W. Blayney, M. Robert-Guroff, M. G. Sarngadharan, V. S. Kalyanaraman, P. S. Sarin, E. S. Jaffe, and R. C. Gallo. 1983. Epidemiology of human T-cell leukemia/ lymphoma virus. J. Infect. Dis. 147:406-416.

12. Blattner, W. A., V. S. Kallyanaraman, M. Robert-Gurofi, T. A. Lister, D. A. G. Galton, P. S. Sarin, M. H. Crawford, D. Catovsky, M. Greaves, and R. C. Gallo. 1982. The human type C retrovirus, HTLV, in blacks from the Caribbean region, and relationship to adult T-cell leukemia/lymphoma. Int. J. Cancer 30:257-264.

13. Böhnlein, E., M. Siekevitz, D. W. Ballard, J. W. Lowenthal, L. Rimsky, H. Bogerd, J. Hoffman, Y. Wano, B. R. Franza, and W. C. Greene. 1989. Stimulation of human immunodeficiency virus type I enhancer by the human T-cell leukemia virus type I tax gene product involves the activation of inducible cellular proteins. J. Virol. 63:1578-1586.

14. Bours, V., J. Villalobos, P. R. Burd, K. Kelly, and U. Siebenlist. 1990. Cloning of a mitogen-inducible gene encoding a $\mathrm{kB}$ DNA-binding protein with homology to the rel oncogene and to cell-cycle motifs. Nature (London) 348:76-80.

15. Bours, V., J. Villalobos, P. R. Burd, K. Kelly, and U. Siebenlist. 1992. A novel mitogen-inducible gene product related to $\mathrm{p} 50$ p105-NF-kB participates in transactivation through a $\mathrm{kB}$ site. Mol. Cell. Biol. 12:685-695.

16. Brownell, E., N. Mittereder, and N. Rice. 1989. A human rel proto-oncogene cDNA containing an Alu fragment as a potential coding exon. Oncogene 4:935-942.

17. Catovsky, D., M. Rose, A. W. G. Goolden, J. M. White, G. Bourikas, A. I. Brownell, W. A. Blattner, M. F. Greaves, D. A. G. Galton, D. R. McCluskey, I. Lampert, R. Ireland, J. M. Bridges, and R. C. Gallo. 1982. Adult T-cell leukemia/lymphoma in blacks from the West Indies. Lancet i:639-643.

18. Cesarman, E., A. Chadburn, G. Inghirami, G. Gaidano, and D. M. Knowles. 1992. Structural and functional analysis of oncogenes and tumor suppressor genes in adult T-cell leukemia/ lymphoma shows frequent p53 mutations. Blood 80:3205-3216.

19. Chen, I. S. Y., D. J. Slamon, J. D. Rosenblatt, N. P. Shah, S. G. Quan, and W. Wachsman. 1985. The $x$ gene is essential of HTLV replication. Science 229:54-58.

20. Crenon, I., C. Béraud, P. Simard, J. Montagne, P. Veschambre, 
and P. Jalinot. 1993. The transcriptionally active factors mediating the effect of the HTLV-I Tax transactivator on the IL2-R $\alpha$ $\mathrm{KB}$ enhancer include the product of the c-rel proto-oncogene. Oncogene 8:867-875.

21. Cross, S. L., M. B. Feinberg, J. B. Wolf, N. J. Holbrook, F. Wong-Staal, and W. J. Leonard. 1987. Regulation of the human interleukin-2 receptor $\alpha$ chain promoter: activation of a non functional promoter by the transactivator gene of HTLV-I. Cell 49:47-56.

22. Fan, C. M., and T. Maniatis. 1991. Generation of p50 subunit of NF-kB by processing of p105 through an ATP-dependent pathway. Nature (London) 354:395-398.

23. Fleming, A. F., R. Maharajan, M. Abraham, A. G. Kulkarni, S. R. Bhusnurmath, R. A. Okpara, E. Williams, I. Akinsete, J. Schneider, H. Bayer, and G. Hunsmann. 1986. Antibodies to HTLV-I in Nigerian blood-donors, their relatives and patients with leukaemias, lymphomas and other diseases. Int. J. Cancer 38:809-813.

24. Franzoso, G., V. Bours, S. Park, M. Tomita-Yamaguchi, K. Kelly, and U. Siebenlist. 1992. The candidate oncoprotein Bcl-3 is an antagonist of $\mathbf{p} 50 / \mathrm{NF}-\mathrm{kB}$-mediated inhibition. Nature (London) 359:339-342.

25. Fujii, M., P. Sassone-Corsi, and I. M. Verma. 1988. c-fos promoter transactivation by the $\operatorname{tax}_{1}$ protein of human $\mathrm{T}$-cell leukemia virus type I. Proc. Natl. Acad. Sci. USA 85:85268530.

26. Fujii, M., H. Tsuchiya, T. Chuhjo, T. Akizawa, and M. Seiki. 1992. Interaction of HTLV-I Taxl with $\mathrm{p} 67^{\mathrm{SRF}}$ causes the aberrant induction of cellular immediate early genes through CArG boxes. Genes Dev. 6:2066-2076.

27. Gallo, R. C., V. S. Kalyanaraman, M. G. Sarngadharan, A. Sliski, E. C. Vonderheid, M. Maeda, Y. Nakao, K. Yamada, Y. Ito, N. Gutensohn, S. Murphy, P. A. Bunn, D. Catovsky, M. F. Greaves, D. W. Blayney, W. Blattner, W. F. H. Jarrett, H. zur Hausen, M. Seligmann, J. C. Brouet, B. F. Haynes, B. V. Jegasothy, E. Jafie, J. Cossman, S. Broder, R. I. Fisher, D. W. Golde, and M. Robert-Gurofi. 1983. Association of the human type $C$ retrovirus with a subset of adult T-cell cancers. Cancer Res. 43:3892-3899.

28. Ganchi, P. A., S.-C. Sun, D. W. Ballard, and W. C. Greene. 1992. IKB/MAD-3 masks the nuclear localization signal of NF- $\mathrm{B}$ p65 and acts with the C-terminal activation domain to inhibit NF-kB p65 DNA binding. Mol. Biol. Cell 3:1339-1352.

29. Geisler, R., A. Bergmann, Y. Hiromi, and C. Nusslein-Volhard. 1992. cactus, a gene involved in dorsoventral pattern formation of Drosophila, is related to the I $\mathrm{B}$ gene family of vertebrates. Cell 71:613-621.

30. Gessain, A., F. Barin, J. C. Vernant, O. Gout, L. Maurs, A. Calender, and G. de The. 1985. Antibodies to the human T-lymphotropic virus type-1 in patients with tropical spastic paraparesis. Lancet ii:407-410.

31. Ghosh, S., A. M. Gifiord, L. R. Riviere, P. Tempst, G. P. Nolan, and D. Baltimore. 1990. Cloning of the p50 DNA binding subunit of NF-kB: homology to rel and dorsal. Cell 62:1019-1029.

32. Gibbs, W. N., W. S. Lofters, N. Campbell, B. Hanchard, L. La Grenade, B. Cranston, J. Hendriks, E. S. Jafie, C. Saxinger, M. Robert-Guroff, R. C. Gallo, J. Clark, and W. A. Blattner. 1987. Non-Hodgkin lymphoma in Jamaica and its relation to adult T-cell leukemia/lymphoma. Ann. Intern. Med. 106:361-368.

33. Gilmore, T. D. 1990. NF-кB, KBF1, dorsal, and related matters. Cell 62:841-843.

34. Gilmore, T. D. 1991 . Malignant transformation by mutant rel proteins. Trends Genet. 7:318-322.

35. Green, P. L., and I. S. Y. Chen. 1990. Regulation of human T-cell leukemia virus expression. FASEB J. 4:169-175.

36. Haskill, S., A. A. Beg, S. M. Tompkins, J. S. Morris, A. D. Yurochko, A. Sampson-Johannes, K. Mondal, P. Ralph, and A. S. Baldwin Jr. 1991. Characterization of an immediate-early gene induced in adherent monocytes that encodes IKB-like activity. Cell 65:1281-1289.

37. Hatada, E. N., A. Nieters, F. G. Wulczyn, M. Naumann, R. Meyer, G. Nucifora, T. W. McKeithan, and C. Scheidereit. 1992. The ankyrin repeat domains of the NF-kappa B precursor p105 and the protooncogene $b c l-3$ act as specific inhibitors of NFkappa B DNA binding. Proc. Natl. Acad. Sci. USA 89:24892493.

38. Hinrichs, S. H., M. Nerenberg, K. Reynolds, G. Khoury, and G. Jay. 1987. A transgenic mouse model for human neurofibromatosis. Science 237:1340-1343.

39. Hinuma, Y., H. Komoda, T. Chosa, T. Kondo, M. Kohakura, T. Takenaka, M. Kikuchi, M. Ichimaru, K. Yunoki, I. Sato, R. Matsuo, Y. Takiuchi, H. Uchino, and M. Hanaoka. 1982. Antibodies to adult T-cell leukemia-virus-associated antigen (ATLA) in sera from patients with ATL and controls in Japan: a nation-wide sero-epidemiologic study. Int. J. Cancer 29:631635.

40. Hirai, H., J. Fujisawa, T. Suzuki, K. Ueda, M. Muramatsu, A. Tsuboi, N. Arai, and M. Yoshida. 1992. Transcriptional activator Tax of HTLV-I binds to the NF-кB precursor p105. Oncogene 7:1737-1742.

41. Holbrook, N., A. Gulino, and F. Ruscetti. 1987. Cis-acting transcriptional regulatory sequences in the gibbon ape leukemia virus (GALV) long terminal repeat. Virology 157:211-219.

42. Inoue, J., M. Seiki, T. Taniguchi, S. Tsuru, and M. Yoshida. 1986. Induction of interleukine-2 receptor gene expression by p40 encoded by human T-cell leukemia virus type I. EMBO J. 5:2883-2888.

43. Inoue, J. I., L. D. Kerr, A. Kakizuka, and I. M. Verma. 1992. I $\mathrm{B} \gamma$, a $70 \mathrm{kd}$ protein identical to the C-terminal half of p110 NF-кB: a new member of the IкB family. Cell 68:1109-1120.

44. Jafie, E. S., W. A. Blattner, D. W. Blayney, P. A. Bunn, J. Cossman, M. Robert-Gurofi, and R. C. Gallo. 1984. The pathologic spectrum of adult T-cell leukemia/lymphoma in the United States. Am. J. Surg. Pathol. 8:263-275.

45. Kidd, S. 1992. Characterization of the Drosophila cactus locus and analysis of interactions between cactus and dorsal proteins. Cell 71:623-635.

46. Kieran, M., V. Blank, F. Logeat, J. Vandekerckhove, F. Lottspeich, O. Le Bail, M. B. Urban, P. Kourilsky, P. A. Baenerle, and A. Israel. 1990. The DNA binding subunit of NF-kB is identical to factor KBF-1 and homologous to the rel oncogene product. Cell 62:1007-1018.

47. Kim, J. H., and D. T. Durack. 1988. Manifestations of human T-lymphotropic virus type I infection. Am. J. Med. 84:919-928.

48. Levine, P. H., W. A. Blattner, J. Clark, R. Tarone, E. M. Maloney, E. M. Murphy, R. C. Gallo, M. Robert-Gurofi, and W. C. Saxinger. 1988. Geographic distribution of HTLV-I and identification of a new high-risk population. Int. J. Cancer 42:7-12.

49. Liou, H.-C., P. N. Garry, S. Ghosh, T. Fujita, and D. Baltimore. 1992. The NF-kB p50 precursor, p105, contains an internal IKB-like inhibitor that preferentially inhibits p50. EMBO J. 11:3003-3009.

50. Maruyama, M., H. Shibuya, H. Harada, M. Hatakeyama, M. Seiki, T. Fujita, J. I. Inoue, M. Yoshida, and T. Taniguchi. 1987. Evidence for aberrant activation of the interleukin-2 autocrine loop by HTLV-I-encoded $\mathrm{p} 40 \mathrm{x}$ and $\mathrm{T} 3 / \mathrm{Ti}$ complex triggering. Cell 48:343-350.

51. Mercurio, F., J. Didonato, C. Rosette, and M. Karin. 1992. Molecular cloning and characterization of a novel Rel/NF-kB family member displaying structural and functional homology to NF-kB p50/p105. DNA Cell. Biol. 11:523-537.

52. Mercurio, F., J. A. DiDonato, C. Rosette, and M. Karin. 1993. p105 and p98 precursor proteins play an active role in NF- $\mathrm{KB}$ mediated signal transduction. Genes Dev. 7:705-718.

53. Meyer, R., E. N. Hatada, H.-P. Hohmann, M. Haiker, C. Bartsch, U. Rothlisberger, H.-W. Lahm, E. J. Schlaeger, A. P. G. M. van Loon, and C. Schreidereit. 1991. Cloning of the DNA-binding subunit of human nuclear factor $\kappa B$ : the level of its mRNA is strongly regulated by phorbol ester or tumor necrosis factor $\alpha$. Proc. Natl. Acad. Sci. USA 88:966-970.

54. Nagata, K., K. Ohtani, M. Nakamura, and K. Sugamura. 1989. Activation of endogenous c-fos proto-oncogene by human T-cell leukemia virus type I-encoded $\mathrm{p} 40^{\text {sax }}$ protein in the human T-cell line, Jurkat. J. Virol. 63:3220-3226.

55. Naumann, M., F. G. Wulczyn, and C. Scheidereit. 1993. The 
$\mathrm{NF}-\mathrm{kB}$ precursor p105 and the proto-oncogene product $\mathrm{Bcl}-1$ are IKB molecules and control nuclear translocation of NF-kB. EMBO J. 12:213-222.

56. Nerenberg, M., S. H. Hinrichs, R. K. Reynolds, G. Khoury, and G. Jay. 1987. The tat gene of human T-lymphotropic virus type I induces mesenchymal tumors in transgenic mice. Science 237:1324-1329.

57. Neri, A., C.-C. Chang, L. Lombardi, M. Salina, P. Corradini, A. T. Maiolo, R. S. K. Chaganti, and R. Dalla-Favera. 1991. B cell lymphoma-associated chromosomal translocation involves candidate oncogene $l y t-10$, homologous to NF-кB p50. Cell 67:1075-1087.

58. Nolan, G. P., S. Ghosh, H.-C. Liou, P. Tempst, and D. Baltimore. 1991. DNA binding and IKB inhibition of the cloned p65 subunit of NF-кB, a rel-related polypeptide. Cell 64:961-968.

59. Ohno, H., G. Takimoto, and T. W. McKeithan. 1990. The candidate proto-oncogene $b c l-3$ is related to genes implicated in cell lineage determination and cell cycle control. Cell 60:991997.

60. Osame, M., K. Usuku, N. Ijichi, H. Amitani, A. Igata, M. Matsumoto, and H. Tara. 1986. HTLV-I associated myelopathy, a new clinical entity. Lancet i:1031-1032.

61. Poiesz, B. F., F. W. Ruscetti, A. F. Gazdar, P. A. Bunn, J. D. Minna, and R. C. Gallo. 1980. Detection and isolation of a type $\mathrm{C}$ retrovirus particles from fresh cultured lymphocytes of a patient with cutaneous T-cell lymphoma. Proc. Natl. Acad. Sci. USA 77:7415-7419.

62. Pozzatti, R., J. Vogel, and G. Jay. 1990. The human T-lymphotropic virus type I tax gene can cooperate with the ras oncogene to induce neoplastic transformation of cells. Mol. Cell. Biol. 10:413-417.

63. Rice, N. R., M. L. MacKichan, and A. Israel. 1992. The precursor of NF-kB p50 has IкB-like functions. Cell 71:243-253.

64. Ruben, S., H. Poteat, T. H. Tan, K. Kawakami, R. Roeder, W. Haseltine, and C. A. Rosen. 1988. Cellular transcription factors and regulation of the IL-2 receptor gene expression by HTLV-I tax gene product. Science 241:89-91.

65. Ruben, S. M., P. J. Dillon, R. Shcreck, T. Henkel, C.-H. Chen, M. Maher, P. A. Baeuerle, and C. A. Rosen. 1991. Isolation of a rel-related human cDNA that potentially encodes the $65-\mathrm{kD}$ subunit of NF-кB. Science 251:1490-1493.

66. Ryseck, R.-P., P. Bull, M. Takamiya, V. Bours, U. Siebenlist, P. Dobrzanski, and R. Bravo. 1992. RelB, a new Rel family transcription activator that can interact with p50-NF-кB. Mol Cell. Biol. 12:674-684.

67. Sakashita, A., T. Hattori, C. W. Miller, H. Suzushima, N. Asou, K. Takatsuki, and H. P. Koefiler. 1992. Mutations of the p53 gene in adult T-cell leukemia. Blood 79:477-480.

68. Schmid, R. M., N. D. Perkins, C. S. Duckett, P. C. Andrews, and G. J. Nabel. 1991. Cloning of an NF-kB subunit which stimulates HIV transcription in synergy with p65. Nature (London) 352:733-736.

69. Schmitz, M. L., and P. Baeuerle. 1991. The p65 subunit is responsible for the strong transcription activating potential of NF-кB. EMBO J. 10:3805-3817.

70. Siekevitz, M., M. B. Feinberg, N. Holbrook, F. Wong-Staal, and W. C. Greene. 1987. Activation of interleukin 2 and interleukin 2 receptor (Tac) promoter expression by the transactivator (tat) gene product of human T-cell leukemia virus type I. Proc. Natl. Acad. Sci. USA 84:5389-5393.

71. Smith, M. R., and W. C. Greene. 1990. Identification of HTLV-I tax trans-activator mutants exhibiting novel transcriptional phenotypes. Genes Dev. 4:1875-1885.

72. Smith, M. R., and W. C. Greene. 1991. Molecular biology of type I human T-cell leukemia virus (HTLV-I) and adult T-cell leukemia. J. Clin. Invest. 87:761-766.

73. Smith, M. R., and W. C. Greene. 1991. Type I human T-cell leukemia virus Tax protein transforms rat fibroblasts through the cyclic adenosine monophosphate response element binding protein/activating transcription factor pathway. J. Clin. Invest. 88:1038-1042.

74. Smith, M. R., and W. C. Greene. 1992. Characterization of a novel nuclear localization signal in the HTLV-I Tax transactivator protein. Virology 187:316-320.

75. Sodroski, J., C. Rosen, W. C. Goh, and W. Haseltine. 1985. A transcriptional activator protein encoded by the $\mathrm{x}$-lor region of the human T-cell leukemia virus. Science 228:1430-1434.

76. Stein, B., H. Rahmsdorf, A. Stefien, M. Litfin, and P. Herrlich. 1989. UV-induced DNA damage is an intermediate step in UV-induced expression of human immunodeficiency virus type 1, collagenase, c-Fos, and metallothionein. Mol. Cell. Biol. 9:5169-5181.

77. Stephens, R. M., N. R. Rice, R. R. Hiebsch, B. H. R., and R. V. Gilden. 1983. Nucleotide sequence of $v$-rel: the oncogene of the reticuloendotheliosis virus. Proc. Natl. Acad. Sci. USA 80: 6229-6232.

78. Steward, R. 1987. Dorsal, an embryonic polarity gene in Drosophila, is homologous to the vertebrate proto-oncogene, $c$-rel. Science 238:692-694.

79. Sun, S.-C., P. A. Ganchi, D. W. Ballard, and W. C. Greene.

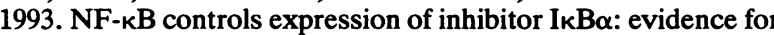
an inducible autoregulatory pathway. Science 259:1912-1915.

80. Sun, S. C., P. Ganchi, C. Béraud, D. W. Ballard, and W. C. Greene. Autoregulation of the NF-kB p65 transactivator by multiple cytoplasmic inhibitors containing ankyrin motifs. Proc. Natl. Acad. Sci. USA, in press.

81. Suzuki, T., J. I. Fujisawa, M. Toita, and M. Yoshida. 1993. The trans-activator tax of human $\mathrm{T}$-cell leukemia virus type 1 (HTLV-I) interacts with cAMP-responsive element (CRE) binding and CRE modulator proteins that bind to the 21-base-pair enhancer of HTLV-I. Proc. Natl. Acad. Sci. USA 90:610-614.

82. Tanaka, A., C. Takahashi, S. Yamaoka, T. Nosaka, M. Maki, and M. Hatanaka. 1990. Oncogenic transformation by the $\operatorname{tax}$ gene of human T-cell leukemia virus type I in vitro. Proc. Natl. Acad. Sci. USA 87:1071-1075.

83. Uchiyama, T., J. Yodoi, K. Sagawa, K. Takatsuki, and H. Uchino. 1977. Adult T-cell leukemia: clinical and hematologic features of 16 cases. Blood 50:481-492.

84. Urban, M. B. and P. A. Baeuerle. 1990. The 65-kD subunit of $\mathbf{N F}-\kappa \mathbf{B}$ is a receptor for $\mathbf{I} \mathbf{B}$ and a modulator of DNA-binding specificity. Genes Dev. 4:1975-1984.

85. Wilhelmsen, K. C., K. Eggleton, and H. M. Temin. 1984 Nucleic acid sequence of the oncogene $\mathrm{v}$-rel in reticuloendotheliosis virus strain $\mathrm{T}$ and its cellular homolog, the protooncogene c-rel. J. Virol. 52:172-182.

86. Wulczyn, F. G., M. Naumann, and C. Scheidereit. 1992. Candidate proto-oncogene $b c l-3$ encodes a subunit-specific inhibitor of transcription factor NF-kB. Nature (London) 358:597-599.

87. Yoshida, M., I. Miyoshi, and Y. Hinuma. 1982. Isolation and characterization of retrovirus from cell lines of human adult T-cell leukemia and its implication in the disease. Proc. Natl. Acad. Sci. USA 79:2031-2035.

88. Zabel, U., and P. A. Baeuerle. 1990. Purified human IkB can rapidly dissociate the complex of the NF- $\mathrm{BB}$ transcription factor with its cognate DNA. Cell 61:255-265.

89. Zhao, L. J., and C. Z. Giam. 1991. Interaction of T-cell lymphotropic virus type I (HTLV-I) transcriptional activator Tax with cellular factors that bind specifically to the 21-basepair repeats in the HTLV-I enhancer. Proc. Natl. Acad. Sci. 88:11445-11449.

90. Zhao, L. J., and C. Z. Giam. 1992. Human T-cell lymphotropic virus type I (HTLV-I) transcriptional activator, Tax, enhances CREB binding to HTLV-I 21-base-pair repeats by protein protein interaction. Proc. Natl. Acad. Sci. USA 89:7070-7074. 